\title{
Umbilical Cord Blood Transplantation in Children and Adults
}

\author{
Jaime Sanz, Paul Veys, and Vanderson Rocha
}

\subsection{Introduction}

Umbilical cord blood transplantation (UCBT) from unrelated donors is a suitable option of HSCT for patients in whom it is indicated, and a suitable related or unrelated BM or PB donor is not available in due time.

Since the 1990s, the majority of UCBT have been performed in children, but the number in adults was growing steadily. In fact, since 2004 the number of UCBT in adults registered in Eurocord was higher than in children. However, a certain decline in the UCBT activity has been observed over the last few years, which is mainly due to an increasing activity of partially matched related (haploidentical) HSCT. It should be noted that, although both options compete in the same

J. Sanz $(\bowtie)$

Department of Medicine, University Hospital La Fe,

University of Valencia, Valencia, Spain

e-mail: sanz_jai@gva.es

P. Veys

Great Ormond Street Hospital (GOSH) for Children

NHS Foundation Trust, and University College

London GOSH Institute of Child Health,

London, UK

V. Rocha

Hospital de Clinicas, Hematology, Transfusion and Cell Therapy Service, University of São Paulo,

Sao Paulo, Brazil

Churchill Hospital, NHS-BT, Oxford University, Oxford, UK niche, their comparative data are very limited and randomized studies are not yet available. As far as we know, two phase III randomized studies are currently ongoing to compare UCBT and haploHSCT in the RIC and MAC setting (NCT0159778 and NCT02386332, respectively).

\subsection{Potential Advantages and Disadvantages of UCBT}

\begin{tabular}{|c|c|}
\hline \multicolumn{2}{|l|}{ UCBT versus BMT/PBSCT } \\
\hline Advantages & Disadvantages \\
\hline $\begin{array}{l}\text { - Expanded access to } \\
\text { transplant } \\
\text { - Higher availability of } \\
\text { donor }^{\mathrm{a}} \\
\text { - Faster search and } \\
\text { shorter time to } \\
\text { transplant }^{\mathrm{a}} \\
\text { - Greater HLA } \\
\text { disparity allowed with } \\
\text { low incidence of } \\
\text { GVHD } \\
\text { - Lower risk of } \\
\text { transmission of viral } \\
\text { infections } \\
\text { - More versatile transplant } \\
\text { planning } \\
\text { - No risk of donor refusal } \\
\text { - No risk to the donor }\end{array}$ & $\begin{array}{l}\text { - Slower engraftment } \\
\text { - Higher risk of non- } \\
\text { immunological rejection } \\
\text { (graft failure) } \\
\text { - Remote possibility of } \\
\text { transmission of a genetic } \text { disease } \\
\text { - Greater delay in immune } \\
\text { reconstitution } \\
\text { - No possibility of donor } \\
\text { lymphocyte infusion }\end{array}$ \\
\hline
\end{tabular}

Similar to UCBT, haplo-HSCT can also be used on an urgent basis and extends donor availability to the vast majority of patients. In addition, 
haplo-HSCT allows a DLI if necessary. Unfortunately, comparative data of these two approaches are limited and inconclusive (Brunstein et al. 2011; Ruggeri et al. 2015), and randomized studies are still lacking.

\subsection{Indications}

Except for some patients with severe BMF, such as aplastic anemia and paroxysmal nocturnal hemoglobinuria, UCBT in adults is performed almost exclusively in patients with malignant hematological diseases. However, UCBT in children has been used for many other nonmalignant diseases, including primary immunodeficiency diseases and inherited metabolic disorders (see Eurocord experience in Table 64.1).

The American Society for Blood and Marrow Transplantation (ASBMT), EBMT, and British Society of Blood and Marrow Transplantation (BSBMT) have recently published their respective guidelines that include recommendations for transplant indications in children and adults. It should be noted that the ASBMT did not differ-

Table 64.1 Distribution by diseases of UCBT registered in Eurocord (1994-2017)

\begin{tabular}{|c|c|c|}
\hline & $\begin{array}{l}\text { Children }(n= \\
\text { 4128) } n(\%)\end{array}$ & $\begin{array}{l}\text { Adults }(n= \\
\text { 3733) } n(\%)\end{array}$ \\
\hline Malignant disorders & $2569(62)$ & $3609(97)$ \\
\hline - AML & $761(18)$ & $1504(40)$ \\
\hline - ALL & $1329(32)$ & 706 (19) \\
\hline - MDS/MPS & $367(9)$ & 703 (19) \\
\hline $\begin{array}{l}\text { - Lymphoid mature } \\
\text { disorders }\end{array}$ & $86(2)$ & $544(15)$ \\
\hline - Plasma cell disorders & $0(0)$ & $114(3)$ \\
\hline - Others & $26(1)$ & $38(1)$ \\
\hline Nonmalignant disorders & $1559(38)$ & $124(3)$ \\
\hline $\begin{array}{l}\text { - Primary } \\
\text { immunodeficiencies }\end{array}$ & $588(14)$ & $6(0.1)$ \\
\hline $\begin{array}{l}\text { - Inborn errors of } \\
\text { metabolism }\end{array}$ & $423(10)$ & $9(0.1)$ \\
\hline $\begin{array}{l}\text { - Bone marrow failure } \\
\text { syndromes }\end{array}$ & $318(8)$ & $104(3)$ \\
\hline - Histiocytic disorders & $180(4)$ & $1(0.1)$ \\
\hline - Others & $50(0.1)$ & $4(0.1)$ \\
\hline
\end{tabular}

$A M L$ acute myeloid leukemia, $A L L$ acute lymphoblastic leukemia, $M D S$ myelodysplastic syndrome entiate recommendations for transplant indications based on donor source (i.e., MRD, URD, UCB, or haploidentical donor) or graft source (i.e., BM, PBSC, or UCB). This is in contrast to guidelines published by the EBMT and BSBMT.

\subsection{Approaches to Improve Outcomes After UCBT}

Apart from refining criteria for UCB unit selection and optimization of conditioning regimens, several strategies have been developed aiming to shorten the time to engraftment and decrease NRM.

\section{Approaches to} improve outcomes

of UCBT Expert point of view

(a) Refining criteria See Chap. 18 of banking, for UCB unit processing, and procurement of selection cord blood cells

(b) Optimization of Specific conditioning regimen can conditioning influence transplant outcomes. regimens See Sect. 64.5

(c) Strategies To date none of these strategies aiming to have consistently shown to shorten the time improve outcomes over single to engraftment unmanipulated UCBT

1. Double UCBT - In children, two randomized trials have demonstrated no benefit and increased risk of GVHD (Wagner et al. 2014; Michel et al. 2016)

- In adults, retrospective studies showed no advantage when single-unit with TNC dose $>2.5 \times 10^{7} / \mathrm{kg}$ available (Scaradavou et al. 2013)

2. Co-infusion Has consistently demonstrated with third- benefit to accelerate party cells hematopoietic recovery. No proved benefit on NRM or survival (Sanz et al. 2017)

3. Ex vivo Promising early studies showing expansion of fast engraftment with different UCB cells expansion techniques. No comparative studies or long-term data (Mehta et al. 2017)

(d) Improvement of Supportive care to prevent or treat supportive opportunistic infections until neutrophil and immune recovery has occurred which is critical in UCBT. See Sect. 64.7 


\subsection{Conditioning Regimens}

The selection of conditioning regimen for HSCT, including UCBT, should take into account the risk of toxicity and the risk of graft failure and relapse in malignant diseases. In UCBT, given the relatively lower cell dose (T-cells and CD34+ cells) and the use of HLA-mismatched grafts, graft failure is of particular concern, especially in adults. The choice of the conditioning regimen is as important as the graft characteristics and can influence transplant outcomes (Ruggeri et al. 2014).

In fact, specific conditioning regimens seem to tolerate infusion of lower cell doses in the graft (Sanz et al. 2013). A comprehensive and exhaustive review of MAC and non-MAC/RIC regimens in the UCBT setting has recently been published (Ross and Gutman 2017).

The Sorror comorbidity index may be a helpful tool to choose the appropriate conditioning intensity for a given patient. Some conditioning regimens options of varying intensity are to be considered:

\begin{tabular}{|c|c|}
\hline \multicolumn{2}{|c|}{ Myeloablative conditioning regimens (MAC) } \\
\hline \multicolumn{2}{|c|}{ Chemotherapy-based } \\
\hline $\begin{array}{l}\text { - Adults: TBF regimen } \\
\text { (Sanz et al. 2012) }\end{array}$ & $\begin{array}{l}\text { TT } 10 \mathrm{mg} / \mathrm{kg}+\text { IV BU } \\
9.6 \mathrm{mg} / \mathrm{kg}+\mathrm{FLU} 150 \mathrm{mg} / \mathrm{m}^{2} \\
+ \text { ATG } 6 \mathrm{mg} / \mathrm{kg}\end{array}$ \\
\hline $\begin{array}{l}\text { - Children: FTT } \\
\text { regimen } \\
\text { (Hough et al. 2016) }\end{array}$ & $\begin{array}{l}\text { TREO } 30-42 \mathrm{~g} / \mathrm{m}^{2}+\text { FLU } \\
150 \mathrm{mg} / \mathrm{m}^{2}+\text { TT } 10 \mathrm{mg} / \mathrm{kg}\end{array}$ \\
\hline $\begin{array}{l}\text { - BF regimen (Admiraal } \\
\text { et al. 2015) }\end{array}$ & $\begin{array}{l}\text { BU }(\text { PK guided })+\text { FLU } \\
160 \mathrm{mg} / \mathrm{m}^{2}+\text { ATG } 19 \mathrm{mg} / \mathrm{kg}\end{array}$ \\
\hline \multicolumn{2}{|l|}{ TBI-based } \\
\hline $\begin{array}{l}\text { - TCF regimen (Barker } \\
\text { et al. 2005) }\end{array}$ & $\begin{array}{l}\text { TBI } 13.2 \mathrm{~Gy}+\mathrm{CY} 120 \mathrm{mg} / \\
\mathrm{kg}+\text { FLU } 75 \mathrm{mg} / \mathrm{m}^{2}\end{array}$ \\
\hline \multicolumn{2}{|c|}{ Medium-intensity conditioning regimens (MIDI) } \\
\hline $\begin{array}{l}\text { - MIDI regimen (Barker } \\
\text { et al. 2017) }\end{array}$ & $\begin{array}{l}\text { TT } 10 \mathrm{mg} / \mathrm{kg}+\text { CY } 50 \mathrm{mg} / \mathrm{kg} \\
+ \text { FLU } 150 \mathrm{mg} / \mathrm{m}^{2}+\text { TBI } \\
4 \text { Gy }\end{array}$ \\
\hline \multicolumn{2}{|c|}{ Reduced-intensity conditioning regimens (RIC) } \\
\hline $\begin{array}{l}\text { - rTCF regimen } \\
\text { (Brunstein et al. 2007) }\end{array}$ & $\begin{array}{l}\text { TBI } 2 \text { Gy + CY } 50 \mathrm{mg} / \mathrm{kg}+ \\
\text { FLU } 200 \mathrm{mg} / \mathrm{m}^{2} \pm \text { ATG }\end{array}$ \\
\hline
\end{tabular}

\subsection{GVHD Prophylaxis}

The most important advantage of UCB over unrelated donor grafts is the capability to tolerate HLA disparities and facilitate a low incidence of chronic GVHD. However, acute GVHD is still one of the most important contributors to morbidity and mortality. Different GVHD prophylaxis regimens have been explored with no evidence of benefit of any specific strategy. MTX is generally not recommended to avoid myelotoxicity and delayed neutrophil recovery although it is widely used in Asia. The most frequently used regimen worldwide is the combination of $\mathrm{CNI}$ for 6-9 months with MMF for 2-6 months.

The use of in vivo TCD with ATG is controversial. ATG in the conditioning regimen has been used to enhance myeloid engraftment as well as to prevent GVHD. Its use has been associated with reduced rates of GVHD. However, although there is no evidence of a negative impact on NRM (Ponce et al. 2015), there is a concern of impaired immune reconstitution and increased viral infections (Chiesa et al. 2012). Recent data suggest that safety of ATG can be improved by adjusting dose with ATG pharmacokinetics (Admiraal et al. 2016).

\subsection{Supportive Care}

The supportive measures described below are not intended to be recommendations but only to be taken into account and to consider their use in the context of each institution's own experience and epidemiology. The most common measures are described merely as a guide since they have a very variable level of evidence (see Table 64.2). 
Table 64.2 Prophylaxis, monitoring, and treatment options to be considered for infections in UCBT

\begin{tabular}{|c|c|c|}
\hline Prophylaxis & Monitoring & Treatment \\
\hline \multicolumn{3}{|c|}{ Supportive measures for bacterial infections } \\
\hline Levofloxacin or ciprofloxacin & $\begin{array}{c}\text { Surveillance cultures to detect } \\
\text { colonization with MDR gram-negative } \\
\text { bacteria }\end{array}$ & $\begin{array}{c}\text { Empirical antibacterial therapy } \\
\text { according to institutional epidemiologic } \\
\text { patterns }\end{array}$ \\
\hline \multicolumn{3}{|c|}{ Supportive measures for fungal infections } \\
\hline Mold-covering azole & $\begin{array}{c}\text { Galactomannan and beta-D-glucan } \\
\text { assays }^{\mathrm{a}}\end{array}$ & $\begin{array}{c}\text { Liposomal AmB, azoles, and/or } \\
\text { echinocandins (according to previous } \\
\text { prophylaxis) }\end{array}$ \\
\hline \multicolumn{3}{|c|}{ Supportive measures for viral infections } \\
\hline CMV: letermovir & $\begin{array}{l}\text { (qPCR) Weekly on days } 0-100 \text { and } \\
\text { then as clinically indicated }\end{array}$ & Ganciclovir, valganciclovir, foscarnet \\
\hline HHV-6: none & (qPCR) as clinically indicated & Ganciclovir, valganciclovir, foscarnet \\
\hline Adenovirus: none & $\begin{array}{l}\text { (qPCR) weekly on days } 0-100 \text { and } \\
\text { then as clinically indicated }{ }^{b}\end{array}$ & Cidofovir \\
\hline EBV: none & $\begin{array}{l}\text { (qPCR) weekly on days } 0-100 \text { and } \\
\text { then as clinically indicated }\end{array}$ & Preemptive rituximab \\
\hline \multicolumn{3}{|c|}{ Supportive measures for protozoal infections } \\
\hline $\begin{array}{l}\text { Pneumocystis: co-trimoxazole, } \\
\text { pentamidine, or atovaquone }\end{array}$ & - & $\begin{array}{l}\text { Co-trimoxazole, pentamidine, or } \\
\text { atovaquone }\end{array}$ \\
\hline $\begin{array}{l}\text { Toxoplasmosis: co-trimoxazole, } \\
\text { atovaquone, or pyrimethamine }\end{array}$ & - & $\begin{array}{l}\text { Co-trimoxazole, atovaquone, or } \\
\text { pyrimethamine }\end{array}$ \\
\hline
\end{tabular}

$M D R$ multidrug-resistant, $A m B$ amphotericin $\mathrm{B}, q P C R$ quantitative PCR

aBoth have been included as microbiological criteria in the definitions of invasive fungal infections by the European Organization for Research and Treatment of Cancer (EORTC) and the Mycoses Study Group (MSG)

${ }^{\mathrm{b} S p e c i a l l y ~ i n ~ c h i l d r e n ~}$

${ }^{\mathrm{c}}$ Reduced-intensity conditioning and ATG are risk factors for EBV-PTLD

Table 64.3 Expected results overall survival at 2 years after UCBT

\begin{tabular}{|l|c|c|c|}
\hline Adults & 2-years OS (\%) & Children & 2-years OS $(\%)$ \\
\hline $\begin{array}{l}\text { Outcomes according to DRI } \\
\text { Low }\end{array}$ & $55 \pm 3$ & Malignant disorders & $49 \pm 1$ \\
\hline Intermediate & $47 \pm 1$ & Acute leukemia & $52 \pm 1$ \\
\hline High & $27 \pm 2$ & MDS & $55 \pm 3$ \\
\hline $\begin{array}{l}\text { Very high } \\
\text { Disease-specific outcomes }\end{array}$ & $19 \pm 3$ & Nonmalignant disorders & $63 \pm 3$ \\
\hline Acute leukemia & $37 \pm 1$ & Inborn error of metabolism & $70 \pm 2$ \\
\hline MDS/MPS & $32 \pm 2$ & Primary immunodeficiency & $68 \pm 9$ \\
\hline Lymphoproliferative disorders & $45 \pm 2$ & Histiocytic disorders & $68 \pm 2$ \\
\hline Plasma cell disorder & $37 \pm 5$ & BMF syndrome & $52 \pm 3$ \\
\hline
\end{tabular}

$D R I$ disease risk index, $M D S$ myelodysplastic syndrome, $M P S$ myeloproliferative syndrome, $O S$ overall survival, $M D S$ myelodysplastic syndrome, $B M F$ bone marrow failure

\subsection{Results (See Table 64.3)}

UCBT outcomes have improved in more recent years, probably explained by better patient and CBU selection, improved conditioning, and supported care. Registry data also showed important center effect with superior survival obtained in experienced centers. Eurocord recently updated clinical results.
Multiple retrospective studies have demonstrated that UCBT offers similar long-term outcomes compared with the gold standard of HLA-matched URD transplants in patients with hematologic malignancies, both in children and adults (Eapen et al. 2007; Brunstein et al. 2010; Atsuta et al. 2012). Interestingly, UCBT seems to offer a potent antileukemic efficacy, through yet unknown mechanisms. A recent report that needs 
to be validated suggested a markedly reduced relapse rate after UCBT as compared to URD transplantation in patients transplanted with MRD (Milano et al. 2016).

\section{Key Points}

- UCB remains a rapidly available and valuable source of stem cells for HSCT.

- In the absence of a fully matched donor available at an appropriate time, similar outcomes are achieved with CBT, MMURD, and haplo-HSCT approaches in the pediatric and adult setting.

- CBT may reduce relapse following HSCT for AML.

- There is a much room for improvement in the field and important progresses are expected in the near future. Decrease in NRM should be the number one goal in future research.

- Strategies to enhance engraftment and, more importantly, approaches to improve immune reconstitution, such as appropriate ATG dosing, are warranted.

\section{References}

Admiraal R, Lindemans CA, van Kesteren C, et al. Excellent T-cell reconstitution and survival depend on low ATG exposure after pediatric cord blood transplantation. Blood. 2016;128:2734-41.

Admiraal R, van Kesteren C, Jol-van der Zijde CM, et al. Association between anti-thymocyte globulin exposure and CD4+ immune reconstitution in paediatric haemopoietic cell transplantation: a multicentre, retrospective pharmacodynamic cohort analysis. Lancet Haematol. 2015;2:e194-203.

Atsuta Y, Morishima Y, Suzuki R, et al. Comparison of unrelated cord blood transplantation and HLAmismatched unrelated bone marrow transplantation for adults with leukemia. Biol Blood Marrow Transplant. 2012;18:780-7.

Barker JN, Kurtzberg J, Ballen K, et al. Optimal practices in unrelated donor cord blood transplantation for hematologic malignancies. Biol Blood Marrow Transplant. 2017;23:882-96.

Barker JN, Weisdorf DJ, DeFor TE, Blazar BR, McGlave PB, Miller JS, Verfaillie CM, Wagner JE. Transplantation of 2 partially HLA-matched umbilical cord blood units to enhance engraftment in adults with hematologic malignancy. Blood. 2005; 105:1343-7.

Brunstein CG, Barker JN, Weisdorf DJ, et al. Umbilical cord blood transplantation after nonmyeloablative conditioning: impact on transplantation outcomes in 110 adults with hematologic disease. Blood. 2007; 110:3064-70.

Brunstein CG, Fuchs EJ, Carter SL, et al. Alternative donor transplantation after reduced intensity conditioning: results of parallel phase 2 trials using partially HLAmismatched related bone marrow or unrelated double umbilical cord blood grafts. Blood. 2011;118:282-8.

Brunstein CG, Gutman JA, Weisdorf DJ, et al. Allogeneic hematopoietic cell transplantation for hematologic malignancy: relative risks and benefits of double umbilical cord blood. Blood. 2010;116:4693-9.

Chiesa R, Gilmour K, Qasim W, et al. Omission of in vivo $\mathrm{T}$-cell depletion promotes rapid expansion of naive CD4+ cord blood lymphocytes and restores adaptive immunity within 2 months after unrelated cord blood transplant. Br J Haematol. 2012;156:656-66.

Eapen M, Rubinstein P, Zhang MJ, et al. Outcomes of transplantation of unrelated donor umbilical cord blood and bone marrow in children with acute leukaemia: a comparison study. Lancet. 2007;369:1947-54.

Hough R, Danby R, Russell N, et al. Recommendations for a standard UK approach to incorporating umbilical cord blood into clinical transplantation practice: an update on cord blood unit selection, donor selection algorithms and conditioning protocols. Br J Haematol. 2016;172:360-70.

Mehta RS, Dave H, Bollard CM, et al. Engineering cord blood to improve engraftment after cord blood transplant. Stem Cell Investig. 2017;4:41.

Michel G, Galambrun C, Sirvent A, et al. Single- vs double-unit cord blood transplantation for children and young adults with acute leukemia or myelodysplastic syndrome. Blood. 2016;127:3450-7.

Milano F, Gooley T, Wood B, et al. Cord-blood transplantation in patients with minimal residual disease. $\mathrm{N}$ Engl J Med. 2016;375:944-53.

Ponce DM, Eapen M, Sparapani R, et al. In vivo T cell depletion with myeloablative regimens on outcomes after cord blood transplantation for acute lymphoblastic leukemia in children. Biol Blood Marrow Transplant. 2015;21:2173-9.

Ross K, Gutman J. Cord blood transplantations. New York: Springer; 2017.

Ruggeri A, Labopin M, Sanz G, et al. Comparison of outcomes after unrelated cord blood and unmanipulated haploidentical stem cell transplantation in adults with acute leukemia. Leukemia. 2015;29:1891-900.

Ruggeri A, Sanz G, Bittencourt H, et al. Comparison of outcomes after single or double cord blood transplantation in adults with acute leukemia using different types of myeloablative conditioning regimen, a retrospective study on behalf of Eurocord and the Acute Leukemia Working Party of EBMT. Leukemia. 2014;28:779-86.

Sanz J, Boluda JCH, Martín C, et al. Single-unit umbilical cord blood transplantation from unrelated donors 
in patients with hematological malignancy using busulfan, thiotepa, fludarabine and ATG as myeloablative conditioning regimen. Bone Marrow Transplant. 2012;47:1287-93.

Sanz J, Kwon M, Bautista G, et al. Single umbilical cord blood with or without $\mathrm{CD} 4^{+}$cells from a third-party donor in adults with leukemia. Blood Adv. 2017;1:1047.

Sanz J, Wagner JE, Sanz MA, et al. Myeloablative cord blood transplantation in adults with acute leukemia: comparison of two different transplant platforms. Biol Blood Marrow Transplant. 2013;19:1725-30.

Scaradavou A, Brunstein CG, Eapen M, et al. Double unit grafts successfully extend the application of umbilical cord blood transplantation in adults with acute leukemia. Blood. 2013;121:752-8.

Wagner JE, Eapen M, Carter S, et al. One-unit versus twounit cord-blood transplantation for hematologic cancers. N Engl J Med. 2014;371:1685-94.

Open Access This chapter is licensed under the terms of the Creative Commons Attribution 4.0 International License (http://creativecommons.org/licenses/by/4.0/), which permits use, sharing, adaptation, distribution and reproduction in any medium or format, as long as you give appropriate credit to the original author(s) and the source, provide a link to the Creative Commons license and indicate if changes were made.

The images or other third party material in this chapter are included in the chapter's Creative Commons license, unless indicated otherwise in a credit line to the material. If material is not included in the chapter's Creative Commons license and your intended use is not permitted by statutory regulation or exceeds the permitted use, you will need to obtain permission directly from the copyright holder. 